\title{
OPTIKAI SZKENNER VIZSGÁLATA
}

\author{
Tóth Dániel \\ tanársegéd, Miskolci Egyetem, \\ Szerszámgépészeti és Mechatronikai Intézet, Szerszámgépek Intézeti Tanszéke \\ 3515 Miskolc, Miskolc-Egyetemváros, e-mail: toth.daniel@uni-miskolc.hu \\ Takács György \\ egyetemi docens, Miskolci Egyetem, \\ Szerszámgépészeti és Mechatronikai Intézet, Szerszámgépek Intézeti Tanszéke \\ 3515 Miskolc, Miskolc-Egyetemváros, e-mail:takacs.gyorgy@uni-miskolc.hu

\section{Szilágyi Attila} \\ egyetemi docens, Miskolci Egyetem, \\ Szerszámgépészeti és Mechatronikai Intézet, Szerszámgépek Intézeti Tanszéke \\ 3515 Miskolc, Miskolc-Egyetemváros, e-mail: szilagyi.attila@uni-miskolc.hu
}

\begin{abstract}
Absztrakt
A tárgyak digitalizálására használt hagyományos tapintók sok esetben nem alkalmazhatók pontosságuk korlátozottsága, a szkennelési idő vagy pusztán az érintés nehézsége miatt. A tárgyak digitalizálása területén az érintés nélküli módszerek egyre nagyobb szerepet játszanak. Ezek sürübb ponthalmazt adnak, igy realisztikusabbak, és a beolvasás ideje is jóval rövidebb.
\end{abstract}

Kulcsszavak: optikai szkenner, digitalizálás, letapogatás

\begin{abstract}
The conventional touch probes used to digitizing objects are not applicable in many cases because of accuracy limitations, time of scanning, or merely the fact of touching. In the field of digitizing objects, the touchless methods play more and more roles. It gives dense points and such a way it is more realistic, and the time scanning is shorter.
\end{abstract}

Keywords: optical scanner, digitization, scanning

\section{Bevezetés}

Az optikai elven müködő szkennerek a testek fizikai geometriájának rögzítésére szolgáló, érintésmentes mérésre alkalmas eszközök, melyek a látható fény tartományában dolgoznak. Mérésre a kontrasztok eltérését és a visszavert fény erősségét használják fel, a klasszikus háromszögelési elv felhasználásával. Az optikai szkenner két fö egysége a projektor és videokamera. A projektor kontrasztrácsot vetít a vizsgálandó objektumra úgy, hogy egyre vékonyabb sávokból álló „fény-sötét” hálót vetít. A fényerősség és a kontrasztrács határterületeinek változása összehasonlítási adatokat hoz létre. A visszaverődési és beesési szög különbsége adja meg a tárgy adott pontban mért kiterjedését és alakját. A különbségek alapján történő átlagolási elv adatokat hoz létre, vagyis a 2 dimenziós fényképezőgépekkel ellentétben adattorzulás nélküli mérési eredményeket kaphatunk. A fényes-sötét kontraszttal végigpásztázott tárgy felületeit, a visszaverődő fényt egy vagy több színes, digitális kamera rögzíti. A CCD- 
től, vagyis digitális kamera képalkotó lapkájától függően változik a kapott kép felbontása, azaz tárgy digitális másolata $[1,2]$.

\section{Vizsgálati eljárás}

A Miskolci Egyetem, Szerszámgépek Intézeti Tanszéke egy Breuckmann Smart Scan 3D-HE típusú háromdimenziós optikai szkennerrel rendelkezik, melynek segítségével ilyen jellegủ szkennelési feladatok elvégzését el tudja látni. A nagyfelbontású szkenner önmagában még nem garantálja azt, hogy a kapott pontfelhő a beolvasni kívánt objektum minden részletét pontosan mutatja. Előfordul, hogy a tárgy sajátossága miatt zavaró, vagy hiányos zavaró információkat (zaj) kapunk a tárgy felszínéröl. Ezek korrigálására professzionális szoftverekre van szükség. A szoftveres javítás elvégzésére a Geomagic Studio szoftver jól használható. A csúcsminőségü Smart Scan 3D-HE mobil szkenner másodperceken belül képes nagy pontosságú 3D koordinátákat szolgáltatni bármilyen tárgyról [3]. Az objektum mérete a különböző objektívkészleteknek jóvoltából széles határok közt változhat, a készülék a bonyolult geometriájú alakzatokat is kiválóan kezeli. Az akár századmilliméter alatti helyzetpontossággal történő pontfelvétel mellett a rendszer az objektum színét is képes felismerni és rögzíteni a 3D-s digitális állományban. A szkenner a látható fény tartományában dolgozik és érintés nélküli mintavételezés útján gyüjti be az információt az objektumok felszínéről. Fő részei a kamerarendszer, mely két, egyenként 5 megapixeles kamerából áll, továbbá a központi projektor, mely az objektumok megvilágítását végzi. Az 1. ábrán látható a megvilágított tárgy és a két kamera képe.
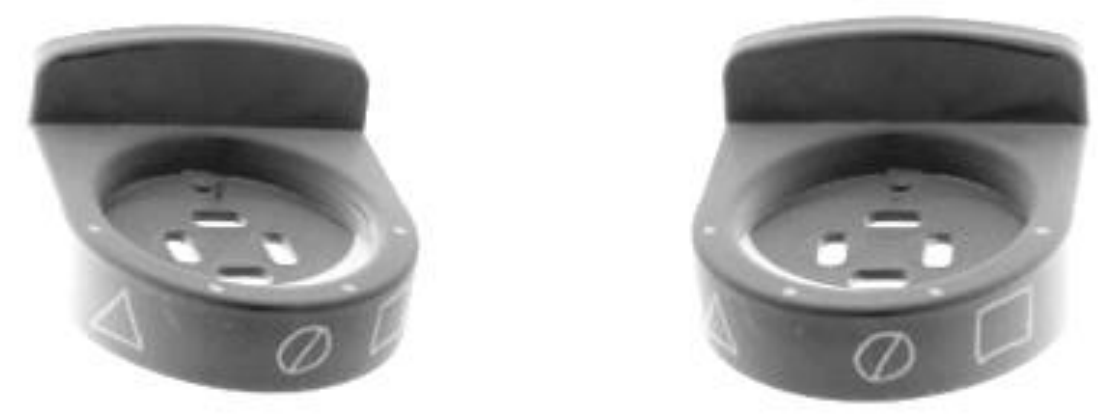

\section{1. ábra. Megvilágított objektum és kamera képek}

A központi projektor egy folyamatosan sürüsödő kontrasztrácsot vetít a felületre, mely függőleges "sötét" és "világos" vonalakból tevődik össze. Ennek a fényrácsnak a letapogatott tárgy felületén történő torzulása szolgáltat információt a felület arculatáról. A torzult fényrácsot fényképezi a két kamera, ezután ezek alapján készíti el a 3D-s pontfelhőt az eszközhöz tartozó szoftver. A kamerák cserélhető lencserendszerrel rendelkeznek, melyek segítségével a látómező mérete változtatható. Az egymás után készített képeket szoftveresen füzzük össze, így a letapogatandó testről teljes 3D-s képet kapunk. A szkennelést vezérlő és adatgyüjtő szoftver az Optocat. A letapogatás után a kamerarendszer látómezejébe eső képek közös metszete jelenik meg számítógépen. Az egymás után készített képeket a szoftver saját, globális koordinátarendszerében helyezi el, így azok más orientációval rendelkeznek, mint a megelőző szkennelések felvételei. A program ezért nem füzi össze automatikusan a képeket, ezt a feladatot "manuálisan" kell elvégezni. A 2. ábrán láthatóak az egymást követő felvételek összefüzetlen állapotban. 


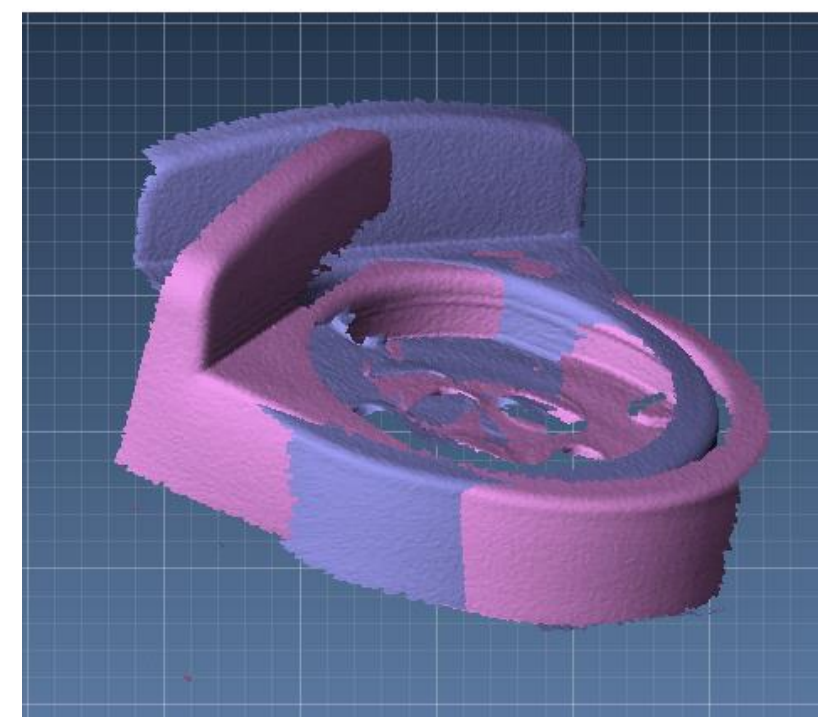

2. ábra. $3 D$ felvételek

Az újabb képeket minden esetben az előző felvételekhez kell illeszteni, hogy a teljes testmodellt megkapjuk. Az összefüzés jelölök segítségével történik, ahogy a 3. ábrán is látható.
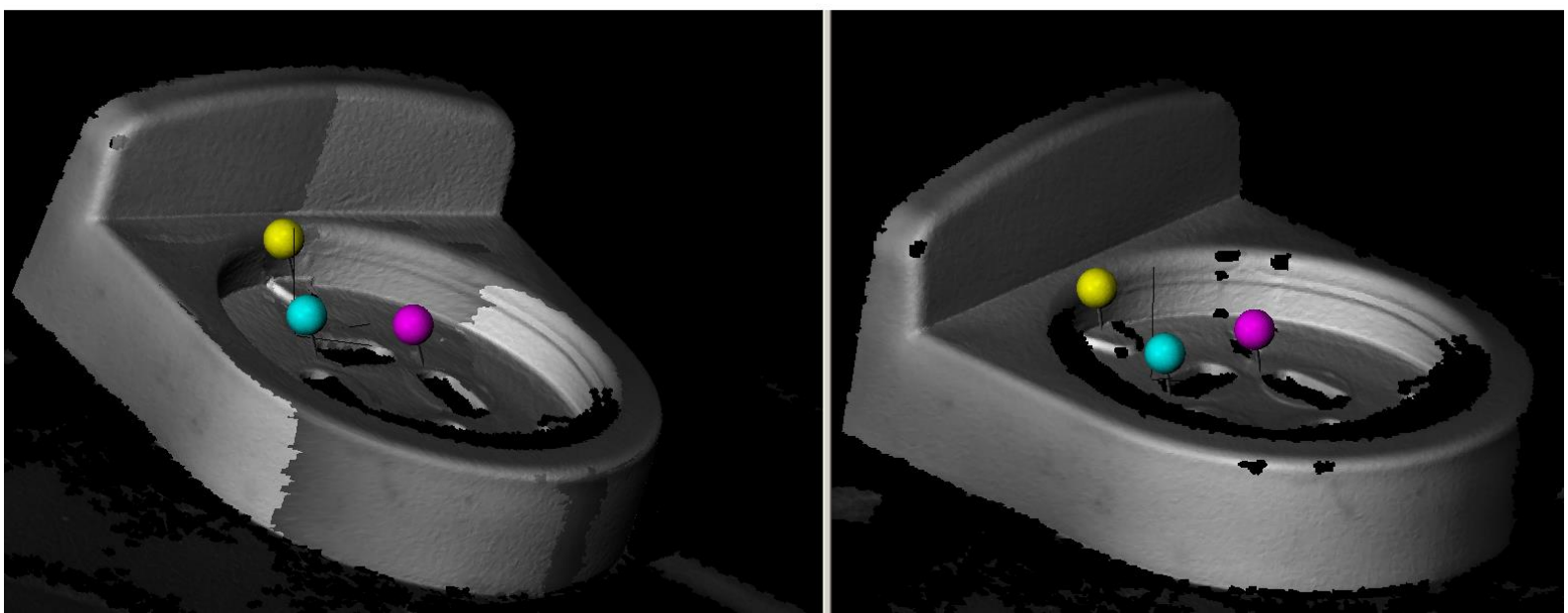

3. ábra. $3 D$ felvételek egymáshoz illesztése

A szoftver a két képen (az utoljára szkennelt rész és az előzőleg összeillesztett részletek) "manuálisan" elhelyezett jelölők környezetében lévő pontokat hasonlítja össze, és az egyezőket egymáshoz rendelve bővíti a modellt. Így tehát megkapjuk a teljes testnek megfelelő 3D-s pontfelhőt. Az Optocat szoftverből elmentett pontfelhőre a Geomagic felületet illeszt, így egyszerübb a módosítás, illetve javítás. Ahogy a 4. ábrán is látható a program segítségével el tudjuk távolítani a felületi kitüremkedéseket, fölösleges pontokat, a létrehozott felületi jelöléseket és meg tudjuk szüntetni az esetleges folytonossági hiányokat. Ezután a javított modell megfelelő fájlformátumba kimentve felhasználható CAD szoftverek vagy RPT technológiák számára. 

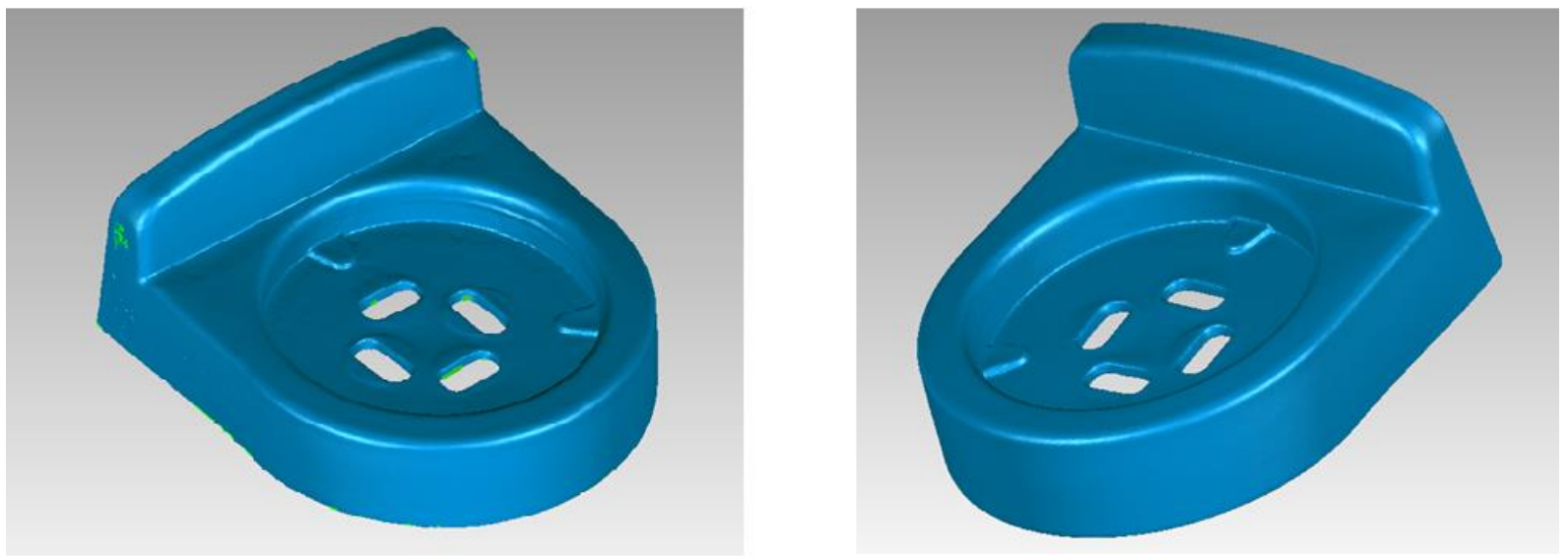

4. ábra. A modell javítása

\section{3. Összefoglalás}

A 3D-s optikai szkennelést felhasználó korszerü eljárás hatékony eszközt nyújt a méret- és alakellenőrzésben, mindemellett jó segítség lehet a bonyolult felületü tárgyak gyártási programjának, illetve technológiájának véglegesítése során.

\section{Köszönetnyilvánítás}

A cikkben ismertetett kutató munka az EFOP-3.6.1-16-2016-00011 jelü „Fiatalodó és Megújuló Egyetem - Innovatív Tudásváros - a Miskolci Egyetem intelligens szakosodást szolgáló intézményi fejlesztése" projekt részeként - a Széchenyi 2020 keretében - az Európai Unió támogatásával, az Európai Szociális Alap társfinanszírozásával valósul meg.

\section{Irodalom}

[1] Zhang, Y.: Research into the engineering application of reverse engineering technology. Journal of Materials Processing Technology 2003, 139:472-475.

https://doi.org/10.1016/S0924-0136(03)00513-2

[2] http://www.tondo.hu/index.php?page=3d_szkenneles_ipar_forma\&menu=m_1_on\&header=h_2 Letöltés dátuma: 2020.06.13.

[3] Breuckmann Szkennerek. https://www.aniwaa.com/product/3d-scanners/aicon-3d-systemsbreuckmann-smartscan/ Letöltés dátuma: 2020.06.13. 